\title{
Memasarkan Demokrasi di Tengah Pasar yang Tidak Demokratik*)
}

\author{
Andre Gunder Frank
}

D

emokrasi Datang dan Pembangunan Keluar" merupakan jargon dunia ketiga. Ide pembangunan dan konsep itu sendiri tampak mengalami tahap krisis. Ide baru yang menggantikannya adalah 'demokrasi'. Ketika Gandhi ditanya pendapatnya tentang 'Peradaban Barat', Gandhi menjawab 'Itu Ide yang cemerlang'. Kita dapat mengatakan pembangunan dan demokrasi satu adanya. Bahkan, untuk dunia ketiga, demokrasi mungkin tidak lebih nyata di masa depan ketimbang pembangunan, atau peradaban barat yang menggejala di masa silam. Demokrasi mungkin hanya menjadi bendera atau lembar daun ara bagi eksplotasi dan opresi yang bersinambung terhadap Selatan oleh pihak Utara.

Dalam kata-kata Abraham Lincoln, Hanya sedikit pemerintahan yang mampu menjadi demokratis sejati dan bermakna, - bagi rakyat, oleh rakyat dan untuk rakyat -di beberapa bagian negara dunia ketiga di Selatan, selama kelogisan ekonomi mereka dan pilihan-pilihan kebijakan nya dikontrol dalam keterlibatannya dengan ekonomi dunia sebagai keseluruhan, yang di laksanakan oleh pihak Utara. Tentu saja, tidak ada jaminan prinsip-prinsip demokrasi menata seluruh kebijakan ekonomi dunia.
Namun selama demokrasi tetap langka dalam ekonomi dunia, demokrasi politik tetap pilihan yang terbaik.

\section{Memperkenalkan "Pembangunan" sebagai pengantar menuju 'Demo- krasi'}

Ideologi Pembangunan telah berkibar sebagai realitas dan kebijakan ekonomipolitik dunia ketiga sejak akhir Perang Dunia Kedua.Namun, keterbelakangan ekonomi terus-menerus terjadi dan bahkan telah merongrong hampir seluruh dunia ketiga di Selatan di hadapan beragam perangkat solusi ideologis dan usaha politik untuk mengatasi nya. Kisah ini bukan hal baru dan mengandaikan sedikit pemerluasan di sini. Namun, di sana muncul beberapa tesis-tesis ironis baru , yang penting dicatat dalam konteks kekinian. Dalam hal ini, saya mungkin mengulangi beberapa refleksi dalam sebagian otobiografi saya belakangan juga esai-esai otokritik 'The underdevelopment of developmen' (Frank, 1991).

\section{Tulisan ini diterjemahkan oleh: Y.F. Anan-} da. 
Pembangunan sistem dunia yang sejati tidak pernah dipandu dengan, atau ditanggapi oleh, behagai pemikiran dan kebijakan pembangunan global atau pun lokal. Di dalam bagian, daerah dan rakyat ekonomi dunia ini, secara temporer dan siklikal mengasumsikan posisi kepemimpinan dan hegemoni pusat (inti) pembangunan sosial dan teknologi. Mereka kemudian memilih menyerahkan tempat kebanggaannya pada siapa yang datang mengatur. Hal ini biasanya menggejala sesudah masa transisipanjang suatu krisis dalam sistem. Sebelumnya, terjadi persaingan yang keras untuk kepemimpinan dan hegemoni. Pusat inti telah bergerák mengelilingi lingkaran dunia dengan supremasi arahan barat.

Pada level negeri-negeri subsistem, daerah-daerah atau sektor-sektor, seluruh 'pembangunan' terjadi melalui, dan pada posisi, yang lebih istimewa di arena kekuasaan dan pembagian-kerja internasional. Gagasan pembangunan nasional dewasa ini merupakan hasil ilusi optik yang miopis. Gagașan-gagasan dan ilusi-ilusi ini diturunkan dari kepentingan- pihak tertentu yang dikelola secara visioner. Hal ini merupakan kelangkaan tanggapan obyektif global dengan pembangunan dunia nyata. Namun ideologi pembangunan yang telah ditancapkan pada persepsi illusif itu, kini bergulir menjemput ajalnya. Konsepsi tersebut sangat tidak memadai untuk dilanjutkan menghadapi realita yang keras. Saat ini diperlukan pengolahan kembali teori pembangunan, seperti teori ekonomi micro-supply dan macro-demand, dengan teori yang lebih dinamik dan dipandu ekonomi supply-and-demand yang di analisa dan dibimbing perkembangan ekonomi dan teknologi dunia.

Ideologi politik dan teori pembangunan yang meluas belakangan ini atau selama dua dekade terakhir itu adalah.'Pembangunan Nasional', yang melalui 'daya ma- gis pasar' mempersilahkan perusahaan bebas mempromosikan pertumbuhan yang dibimbing ekspor. Model yang cemerlang untuk ini adalah Korea Selatan dan Taiwan. Keduanya dianggap sukses di pasar dunia saat ini. Sayangnya, dari kacamata ideologis sukses mereka tidak banyak dikelola oleh perusahaan yang bebas dari intervensi negara. Bahkan, kemampuan mereka untuk melaksanakan dengan baik banyak didukung faktor-faktor politik seperti kolonialisme Jepang sebelum perang, desakan AS untuk reformasi tanah di masa paska-perang, dan subsidi besar-besaran pada era perang dingin.

Melebihi keunikan kasus-kasus ini, tesis bahwa beberapa negeri lain dapat mengcopi kesüksesan mereka adalah suatu Kekeliruan. Pasar dunia tidak akan mampu menyerap ekspor Hong kong sebesar-Cina. Kemungkinan untuk analisis ekonomi yang lebih baik, tidak berarti terdapat suatu model dari, oleh, atau untuk pembangunan yang dapat diterapkan di seluruh dunia.

Keprihatinan para broker ideologi model politik ini, di berbagai negeri di Amerika Latin, Afrika dan Asia Tenggara, yang pada dasarnya juga turut menggunakan strategi pertumbuhan yang dibimbing ekspor (juga sebagian dari negara-negara seperti kota Hong kong dan Singapora), semuanya gagal. Bahkan, kemungkinan mengulangi sukses Korea dan Taiwan kini semakin dipertanyakan (sebagai misal, Bello dan Rosefeld, 1990), karena di kedua negara itu tidak dipaparkan biaya politik dan sosial akibat kediktatoran yang terjadi. Argumentasi pembelaan bagi interevensi negara itu lazim dihubungkan dengan keterasingan (exigencies/isolasi) akibat persaingan di tengah dunia yang sedang berubah, khususnya sebelum resesi ekonomi dunia menggejala tahun 1990.

Dalam kompetisi teknologi di pasar dunia, masih belum jelas siapa yang sukses 
dan menciptakan ukuran untuk bertahan. Secara berbeda bisa dikatakan, di tengah alunan nada-nada musikal ekonomi dunia ini, belum jelas siapa yang masih akan bertahan ketika irama musik berhenti. Mungkin Korea dan Taiwan, tapi lebih mungkin ketidak-suksesan mereka di pasar dunia saat ini sementara menjadi yang terbaik.

Tapi jelas di luar Jepang, sisa-sisa negeri Asia, Afrika, dan Amerika Latin seperti kebanyakan di Eropa Timur dan Republik bekas Uni Soviet tidak memiliki kualitas untuk bertahan. Industrialisasi di negeri-negeri tersebut merupakan hasil dari pasar dunia tradisional berupa bahan-bahan mentah yang nilai kompetitifnya rendah plus upah buruh murah. Pada saat yang sama, pengembangan dan peningkatan teknologi agar tetap kompetitif di pasar dunia telah gagal di kebanyakan di dunia ketiga dan kedua, di berbagai sektor dan penduduk, meski hal itu juga menggejala di beberapa negara industri dunia pertama khususnya di AS.

Apa yang tampak nyata terjadi menumbuhkan tantangan di berbagai negeri, daerah dan rakyat yang akan dimarginalisasikan. Mereka tidak rela melepaskan diri dari proses evolusi atau pembangunan dunia. Namun mereka akan terpental dengan cara yang tidak mereka kehendaki. Kasus yang paling jelas adalah banyak negara sub Sahara Afrika. Di sana terjadi kemerosotan pembagian kerja internasional pasar dunia bagi alam dan SDM Afrika. Setelah kering terperas seperti buah jeruk mengikuti irama pembangunan kapitalis dunia, banyak negara di Afrika kini tinggal' menanti nasib. Lebih jauh, keyakinan yang sama juga meningkat di daerah dan rakyat lainnya di mana saja; di Selatan (misalnya Bangladesh, Brazilian barat daya, Amerika Tengah), di bekas-industri besi-tua, Bronx Selatan dan daerah lain, juga rakyat di
Barat dan seluruh daerah pedalaman bekas Sosialis timur, sebagai contoh, dua sisi perbatasan Cina-Rusia.

Peristiwa-peristiwa yang terjadi di tahun 1989-92 mengakselerasi dan memperparah marginalisasi jutaan manusia di Eropa timur dan bekas Uni soviet. Diwakili Boris Yeltsin, mereka merasa diperlakukan "habis manis sepah dibuang". Setelah penduduk bagian Selatan mengalami demikian panjang eksplotasi di masa silam, keinginan agar hal itu tidak berulang di masa depan menjadi mudah dipahami. Kecenderungan pada (atau kebangkitan dari) etnik tradisional dan identitas nasional atau perselisihan antar-etnik merupakan salah satu tanggapan atas kemerosotan deprivasi ekonomi itu, seperti merajalelanya pengangguran sebesar 30 persen bagian Asia Tengah bekas Uni Soviet. Kemerdekaan politik dan perselisihan inter-etnik di Asia Tengah atau Afrika Tengah kini mampu memberikan rakyat di daerah tersebut sedikit keuntungan ekonomi di masa depan.

Sebaliknya, ketegangan politik yang dimotivasi etnik dan muatan perubahan ekonomi lain, dan bahkan eksploitasi menantang untuk menukar hal-hal itu, secara terpisah dan bersama-sama, dalam keterkucilan sejarah. (Bahkan, pemusatan Asia tengah adalah fakta historis untuk millenia sebelum pengaturan dunia Utara-Selatan saat ini mulai jelas pada abad 16 seperti saya kemukakan dalam Frank 1992). Berbagai daerah ini lebih mungkin ter-Amerika-Latin-kan dan beberapa lagi afrikanisasi dan lebanonisasi, daripada eropanisasi- barat yang mereka idamkan.

Rakyat di berbagai tempat dan tempat-tempat lain kini mungkin dikorbankan demi pembangunan berorientasi pertumbuhan. Mereka menjadi korban persaingan efisiensi pembagian kerja internasional di pasar kapitalis dunia, juga dalam evolusi masyarakat kontemporer. Akibatnya, Barat 
mungkin menerima lebih banyak aliran emigrasi dari beberapa yang mampu, di antara banyak yang ingin, untuk meloloskan diri dari marginalisasi di Amerika Tengah dan Afrika. Amerika utara, Eropa Barat dan Jepang akan menjadi sentra-sentra magnet penariknya. Banyak orang cenderung bertahan hidup meski harus dieksplotasi pembagian kerja di Utara, ketimbang tewas menderita akibat perang dan kelaparan, atau hidup marginal tanpa harapan di Selatan.

Inkorporasi berbagai daerah bagian Dunia ketiga dan bekas dunia kedua ke dalam blok ekonomi Amerika, Eropa barat dan Jepang mungkin tampak kontradiktif dengan proses-proses marginalisasi ini. Tapi bagi mayoritas rakyat yang terlibat inkorporasi, justru menganggapnya semakin mempertegas marginalisasi mereka. Bergabungnya daerah dan sumber daya serta kekuatan buruh atau daya beli mereka dalam blok-blok formasi ekonomi-politik regional tidak lain sekedar untuk menyangga kekuatan-kekuatan ekonomi dan kapasitas persaingan puncak- blok-blok tersebut.

Bahkan, penggabungan pada blok-blok ini dapat terjadi, jika segala sesuatu di peras dari bawah. Di tempat dan saat mana buruh- rakyat atau kemampuan pengeluaran tidak dapat membantu tujuan ini, mereka tetap atau masih dipinggirkan hal yang sama. Dan, tekanan kompetitif baik di dalam mau pun di antara blok-blok ekonomi itu hanya memperburuk proses-proses marginalisasi di antara blok-blok itu, dari atas ke bawah. Itu sebabnya, penduduk Kanada memprotes Pakta perdagangan bebas Amerika-Kanada.

Juru bicara untuk buruh di Kanada, US, dan Meksiko memperingatkan bahwa perluasan zone ini ke Mexico akan meningkatkan blok ekonomi-politik, sekaligus memperkuat dominasi garis politik kekuat- an blok dominan. Selanjutnya hal itu akan mendeprivasi negeri yang bebas untuk menjadi jinak secara politik sehinggga tunduk untuk, meminjam Doktrin Sinatra, "Do it my way", hingga mengalami marginalisasi ekonomi yang lebih parah.

Dengan kata lain, ekonomi dan masyarakat terbelah (dual economy and society) kini barangkali juga telah menjelma dalam evolusi proses formasi di skala global. Perbedaan Dualisme baru dengan dualisme lama sudah saya paparkan di bagian awal tulisan saya (Frank, 1967 dan lain) . Keserupaan antara kedua dualisme hanya tampaknya. Pada dualisme lama, sektor atau daerah-daerah dianggap terpisah. Mereka diandaikan telah hadir tanpa eksplotasi di masa silam atau masa kini sebelum 'modernisasi', keduanya bekerja saling berdampingan dan saling mendukung. Pemisahan eksistensi ganda ini menggejala di dalam berbagai negeri. Saya telah membantah seluruh proposisi-proposisi ini.

Dalam dualisme baru, pemisahan terjadi sesudah kontak dan seringkali sesudah eksplotasi. Ibarat buah jeruk yang ditekan lagi sesudah kering-terperas. Jadi, dualisme baru ini merupakan hasil proses evolusi sosial dan teknologi, yang sering disebut 'pembangunan'. Dualisme baru ini juga menggejala di antara mereka yang bekerja dan yang tidak dapat berpartisipasi dalam pembagian kerja di seantero dunia. Dalam kontek yang lebih melebar, ke dalam dan ke luar pembagian kerja dunia, ditentukan secara teknologis. Bahkan, Dualisme baru ini mungkin sudah terakit dengan dualisme teknologi lama.

Ironisnya, perubahan politik dan ideologi yang sama dewasa ini terjadi di Eropa Timur, melalui aspirasi rakyat untuk bekerja sama dengan dunia pertama di Eropa Barat, yang mengancam Eropa timur menjadi dunia ketiga secara ekonomis, -mengulangi hal yang telah terjadi sebelumnya. 
Polandia sedang dalam proses di-Amerikalatin-kan, Ketergantungan Rumania pada ekspor ekonomi agrikultural Rumania (dan hanya temporer minyak) cukup beruntung jika dapat membantu posisi (kini ditantang Bulgaria) mereka untuk bangkit dan bertahan.

Problem yang sama mengandung a fortiori di republik bekas Uni Soviet, beberapa bagian Rusia dan Ukrania di-Baratkan Peter Agung dan diindustrialisasikan olehnya, juga Witte dan juga Stalin. Tapi hampir seluruh bagian bekas Uni Soviet, sekali pun yang terbaik, serupa dengan ekonomi dunia ketiga seperti Brazil, India dan China yang juga memiliki kapasitas industrial khususnya perangkat keras militer. Transkaukasian dan daerah Asia tengah, tetap dalam persemakmuran Negara Independen atau tidak teramerika- Latinkan, tapi cenderung secara ekonomis seperti Afrika atau, seperti dilarang Tuhan (God forbid), Lebanon secara politik. Keyakinan suram yang serupa adalah apa yang terjadi di Yugoslavia.

Pengalaman pahit di negeri-negeri tersebut tidak dapat dilepaskan dari usaha mereka untuk meloloskan diri dari kurungan kompetisi persaingan ekonomi dunia. $\mathrm{Ne}-$ geri-negeri dunia kedua ini terhalangi dengan posisi mereka dalam pembagian kerja internasional, dan sangat tidak relevan dilindungi dengan demokrasi politik atau dikutuk akibat ketidakhadiran atau kegagalannya. Mereka tertekan karena kekurangan alat tukar internasional, atau dengan kata lain kelangkaan dollar. Peristiwa 1989 atau 90 menghilangkan seluruh legitimasi dan kredibilitas ideologis negeri-negeri Sosialis dunia ini.

Betapa pun, ketika beberapa pengamat membatasi perhatian mereka pada kebangkrutan komponen sosialis beberapa ideologi di Eropa dan Asia atau Afrika, kenyataannya yang terjadi sesungguhnya adalah me- rosotnya sentimen nasionalisme di manamana. Kita mengamati rekaman perbandingan di bawah kebijakan ekonomi Partai Komunis, Diktator militer dan pemerintahan demokratik pengganti mereka.

Tapi ironi ekonomi jangka panjang adalah prospek untuk pembangunan nasional yang lain dengan tujuan politik yang berbeda, sendiri-sendiri atau bersamasama adalah buruk. Dan, prospeknya kini sangat buruk, bagi wilayah dunia ketiga yang terbelakang di Eropa timur dan republik awal Uni soviet, juga kebebasan ideologinasional atau kebijakan negara mereka di negara dunia ketiga yang terbelakang.

\section{Irrelevansi ekonomi- akhir ideologi Politik}

Dekade 80-an ditandai masa transisi dari banyak negara Timur dan Selatan dari ideologi 'pembangunan' menuju 'Demokrasi'. Tapi dekade yang sama juga menunjukkan ir-relevansi ideologi nasionalisme dalam ekonomi dunia internasional. Kebijakan ekonomi-politik Internasional dan nasional yang sangat penting diadopsi dan diimplementasikan di seluruh dunia sebelum 1980, jarang ada yang bertentangan dengan ideologi dominan. Tahap ini menandai irrelevansi yang kuat dengan tanggapan ekonomi-politik yang diperlukan pada kondisi-kondisi ekonomi dunia melampaui kontrol siapa pun.

Dalam tinjauan saya mengenai revolusi di Eropa Timur 1989 (Frank 1990a) dan jawaban saya untuk Francis Fukuyama (Frank 1990b). Saya menunjukkan bahwa tesis ideologis Fukuyama yang menyebutkan 'untuk jangka yang panjang ideologi telah memenangkan pertarungan duria material terhadap dunia material' bertentangan dengan realital. Hal itu bertolak-belakang akhir-akhir ini —dan akan semakin gamblang di masa depan. 
Pada dekade 70-an, strategi pertumbuhan yang dibimbing ekspor/impor yang serupa diadopsi pemerintah yang dipimpin Partai Komunis di Timur (Polandia, Romania, Hungaria) dan kediktatoran Militer di Selatan (Argentina, Brazil, Chili). Pada dekade 80-an, kebijakan pengelolaan hutang yang sama model IMF diadopsi dan diimplementasikan pemerintahan yang dipimpin Partai Komunis di Timur (Polandia, Hungaria, Romania, Yugoslavia) dan dengan kediktatoran militer, pemerintahan otoriter yang lain dan pemerintahan demokratik pengganti mereka di Selatan (Argentina, Brazil, Mexico, Pilipina).

Terdapat berbagai variasi dalam tema pembayaran hutang, tapi sukar untuk mengkorelasikan, apalagi menjelaskan, semuanya dengan referensi warna politik atau rejim-rejim ideologis atau berbagai pemerintahan. Murid paling cemerlang IMF adalah Nicolae Ceaucescue di Romania, yang memotong bantuan hingga harapan lenyap, pertama bagi rakyatnya, kemudian bagi dirinya sendiri. Di Peru, Presiden yang baru terpilih Alan Garcia mendewakan IMF dan mengumumkan akan membatasi pembayaran hutang tak lebih dari $10 \%$ pendapatan ekspor. Sebetulnya lebih kecil dari itu sebelum ia kemukakan secara resmi. Tapi kenyataanya pembayaran hutang meningkat lebih dari $10 \%$ di bawah kepresidenannya. Pendapatan nyata tinggal hanya setengahnya, dan novelis Vargas Llosa berhasil menjadi presiden sesudah bergerak dari politik kiri-tengah menuju ke ekstrem kanan. Tapi apa artinya kemudian?

Rakyat Peru bersuara menentang Vorgas llosa, memilih Fujimori dan mendapat 'Fuji shock'. Kebijakan ekonomi Presiden Fujimori nyatanya serupa dengan rivalnya -yang ditolak pemilinnya dalam pemilu. Sesudah itu datanglah kholera dan coup de e'tat oleh presiden yang sama.
Jendral Komunis Jaruselski di Polandia dan Populis Sandinista di Nicaragua juga mendesakkan "penyesuaian" (adjustment) dan persyaratan gaya IMF bagi rakyat mereka. Kedua negara tersebut dapat melaksanakannya tanpa tekanan dari IMF, sejak Polandia tidak menjadi anggota dan Nicaragua tidak punya akses di dalamnya. Di Nicaragua, hadir Condicionalidad sin fondo yang berdiri tanpa dukungan penyandang Dana (Fund) dan tanpa kebijakan Sisipian dari bawah atau di ujungnya. Hungaria telah menjalankan kebijakan ekonomi yang sangat reformis dan politik yang amat liberal kendati dikendalikan Partai'Komunis dalam Pákta Warsawa. Padahal Hungaria telah melunasi hutangnya di 1980-an sebanyak tiga kali lebih -dan tetap berhutang. Itu melebihi hutang Polandia atau Brazil atau Mexico, yang rata-rata melunasi hutang hanya sekali atau dua kali. Tak ada perubahan nyata baik dari pemerintahan Solidarnösc yang mengganti Jenderal Jaruselski dan Partai Komunis di Polandia yang diuntungkan sebagai keanggotaan IMF dan tekanannya bahkan lebih berat daripada pengorbanan ekonomi daripada pendahulunya.

Jadi apakah perbedaan kebijakan ekonomi di Sosialis Timur sebelum diterapkannya demokrasi-dan ketika demokrasi saat ini tampil di Eropa Timur? Mengapa rezimrezim komunis Gomulka dan Gierek, Jenderal Komunis Jaruselski dan Perdana Menteri Solidarnösc's Mazowiescki semuanya melaksanakan kebijakan yang sama-sama tidak populer? Bahkan, Solidarnosc dan Komunis mengajukan reformasi ekonomi yang pada intinya sama rapuhnya di tahun 1981 sebelum Jenderal Jaruseiski memberlakukan Hukum darurat pada 13 Desember. Pada saat ia kekurangan kekuatan politik untuk mendorong reformasi yang disponsori Solidarnosc, dia memberlakukan hukum darurat menggantikan keinginan rakyat yang diwakili Solidarnösc. 
Tapi di mana dan apa ekspresi demokratik itu ketika Solidarnosc berkuasa, (atau lebih di pemerintahan) dan menggunakan kehendak-baik (goodwill) populernya untuk memperkencang pengetatan ikatpinggang ekonomi yang lebih tidak- populer terhadap penduduk ketimbang pemerintah pendahulunya? Pertanyaan yang sama harus diajukan kepada setiap rejim, terpilih secara demokratis atau tidak, di Hungaria atau di mana saja. Dalam pemilu bebas pertama Hungaria, seluruh partai sepakat mengikuti preskripsi IMF sesudah pemilihan.

Ada pelajaran ideologis yang dapat dipetik dari perbandingan dan pola-pola kebijakan ekonomi- entah itu sukses atau gagal

Dalam kasus-kasus Amerika Latin dan Asia Tenggara, masih mungkin untuk menyerukan 'nasionalisme,' anti imperialisme' dan terkadang juga 'sosialisme' demi memobilisasi oposisi rakyat terhadap kebijakan perampingan ekonomi-politik ini. Tapi pasti tak ada satu tempat pun di Eropa Timur -sejak sosialisme mengalami kebangkrutan - dan partai-partai komunis didiskreditkan. Mereka pada awalnya merekayasa krisis ekonomi domestik dan kemudian mengimplementasikan jasa hutang dan kebijakan perampingan. Dan tentu saja, mereka adalah instrumen yang tunduk pada imperialisme Rusia.

Di sisi lain barat adalah masa depan. Lebih dari itu, kebijakan Barat IMF merupakan 'senjata rahasia' dan kawan-aliansi kelompok oposisi. Mereka kini dalam posisi menawarkan alternatif untuk mengatasi pertama-tama krisis ekonomi dan kemudian krisis politik, dengan implementasi kebijakan perampingan penyesuaian yang didukung IMF dan nasihat serta syarat-syarat Barat lainnya.

Krisis ekonomi terus meluas dan mendalam di Eropa Timur dan Republik bekas
Uni Soviet. Krisis ekonomi dan faktor-faktor yang berkaitan dengan ekonomi secara material itu turut membantu ambisi dan kecakapan gerakan-gerakan sosial untuk memobilisasi banyak orang untuk tujuantujuan politik. Dekade 80 -an, juga permulaan medio 70-an, kini sering disebut periode stagnasi dalam sejarah soviet; mengakselerasikan krisis ekonomi dan deteriorisasi standar kehidupan di sebagian besar negara Eropa Timur (juga termasuk di Amerika latin, Afrika dan beberapa bagian dunia lainnya, vide, Frank 1988) yang memiliki profil 'yang serupa. Yang paling signifikan, khususnya di Eropa Timur, periode ini juga ditandai deteriorisasi penting dan retrogresi dalam keberlangsungan kompetisi dan standar kehidupan jika diperbandingkan dengan Eropa barat, atau bahkan negara industrialisasi baru di Asia Timur.

Lebih jauh, keberlangsungan dan (mis) managemen krisis ekonomi itu telah menghasilkan pergeseran dalam posisi dominasi atau keistimewaan dan ketergantungan atau eksploitasi di antara negeri-negeri, sektorsektor dan perbedaan sosial (termasuk gender) dan kelompok etnik di antara bekas Uni Soviet dan Eropa Timur. Seluruh perubahan ekonomi dan tekanan-tekanan dihasilkan atau dipenuhi muatan sosial, permintaan dan mobilisasi, yang mengekspresikan dirinya melalui pembangkitan gerakan-gerakan sosial (etnik/nationalis) dengan suatu variasi keserupaan dan pembedaan di antara mereka. Hal itu diketahui secara ekonomi berdasarkan dendam akibat kehilangan standar kehidupan absolut yang lazim, seluruhnya atau terbatas untuk hal-hal tertentu, dengan pergeseran relatif kemakmuran ekonomi di antara sejumlah penduduk. Sebagian besar krisis ekonomi mempolarisasikan, bahkan memperkaya, secara relatif kalau justru bukan absolut, yang telah mapan (the better off); dan lebih mempermiskin, secara relatif dan absolut, 
Topik: Memasarkan Demokrasi di Tengah Pasar yang Tidak Demokratik, Andre Gunder Frank

mereka yang rentan khususnya kaum perempuan.

Jadi, momen perubahan ekonomi dan politik Perestroika dan Glasnost di bekas Uni Soviet dan Eropa Timur, simultan dengan itu, akhir perang dingin tidak muncul begitu saja, seperti Pallas Athena (istana Athene) dari Zeus, dari kepala Mikhail Gorbachev. Tapi Gorbachev melihatnya sebagai suatu keniscayaan. Sebagai keharusan (ekonomi) dari induk penemuan (politik), suatu hal yang ada dengan sendirinya bersama Gorbachev, tapi digali dan ditemukan. Praksis pragmatisnya melebihi dan menggulingkan prakonsepsi ideologis, termasuk idenya dan prakonsepsi lawan-lawannya di dalam dan luar negeri. Keterasingan ekonomi dunia melahirkan banyak perilaku praksis pragmatik dan ironi politik dekade 1980-an.

Ironi politiknya adalah 'penampilan-aktual sosialisme' yang gagal total karena implementasi yang tidak sukses dari model pertumbuhan yang dibimbing impor/ekspor dan kebijakan perampingan gaya IMF di Timur. 'Penampilan aktual kapitalisme', yang menerapkan model-model dan kebijakankebijakan yang sama di Selatan juga menderita kegagalan. Bahkan, tak seorang pun di Barat atau di Timur berkomentar, dan juga di Selatan masuk-akal tidaknya alternatif-sosialis itu ditawarkan. Tapi mengapa terdapat suatu 'perubahan sistem' di (bagian dari) Timur mensikapi kegagalan itu, tapi tak ada sama sekali di selatan yang mengalami kegagalan serupa? Jeanne Kirkpatrick keliru ketika mengatakan bahwa negerinegeri totalitarian di timur tidak berubah, ketika kolega-otoritarian baratnya justru berubah. Akhirnya, adalah bertanggung jawab bila kasus yang sama lainnya juga mengalami 'perubahan sistem' atau 'akhir sejarah'. Regim-rejim demokratik baru yang akan mampu menahan dan mengimbangi isolasi ekonomi dunia setidaknya kurang mampu dari pendahulu totalitarian mereka.

\section{Kegandrungan Privatisasi}

Contoh kebingungan idelogis lain adalah apa yang sekarang populer (fashionable) disebut 'privatisasi', yang kerap diidentikkan dengan "Demokrasi". Namun demikian, ideologi yang mempromosikan privatisasi ini bukanlah penawar yang lebih baik bagi penyakit-penyakit Eropa Tengah/ timur, dibandingkan stabilisasi dan kebijakan privatisasi yang sebelumnya digunakan untuk penyakit Amerika Latin atau di mana saja. Bahkan, sebelum menggejalanya resesi di seantero jagat, kebijakan privatisasi ini hanya mendorong kemiskinan semakin merajalela.

Kegandrungan privatisasi sekarang ini, sama halnya seperti kegandrungan nasionalisasi dahulu, irrasional secara ekonomis, dan ideologis secara politik. Itu hanya menghasilkan perbedaan kecil di antara perusahaan yang dikuasai swasta atau publik; keduanya harus saling bersaing dalam kadar yang serupa di pasar dunia. Hanya, pengecualian dari aturan ini adalah perusahaan-perusahaan publik yang disubsidi anggaran belanja negara, dan perusahaan swasta yang juga disubsidi anggaran pemerintah dan/atau sebaliknya terlibat "dalam kepentingan publik". Contoh yang terkenal di AS adalah Korporasi Chrysler Detroit's; Bank Kontinental Chicago dan perusahan Trust (pada saat itu merupakan 8 Bank terbesar AS); Ohio Maryland, California dan Texas savings \& Loans; dan bahkan New York City.

Kenyataannya, di pasar, perusahaan publik dan swasta dapat sekaligus melakukan investasi dan keputusan-keputusan manajemen lainnya sama benar atau kelirunya. Dekade 70-an., Pabrik Baja (publik) British keliru melakukan investasi berlebihan (over-estimated), dan Pabrik Baja 
(privat) AS keliru dengan kurangya investasi (underestimated). Pada tahun 1980, kedua firma menutup pabrik penempaan besi-baja untuk tujuan buruh publik buruh. Baik Industri swasta Jerman di bawah rejim Kristen Demokratik dan Industri Baja Publik di bawah rejim Sosialis Perancis.

Swastanisasi perusahaan publik di Timur dan Selatan yang kini menawarkan harga saham dasar yang meningkat di minggu pertama di bursa saham, merupakan suatu praktek yang sama curangnya dengan nasionalisasi perusahaan yang diciptakan dengan harga-harga di atas nilai pasar dahulu, atau nasionalisasi perusahaan-perusahaan yang menguntungkan dengan sedikit atau tanpa ganti rugi samasekali. Permainan 'sekarang anda lihat, sekarang anda tidak' ini, seluruhnya lebih dalam kasus perusahaan di Timur dan Selatan yang kini diswastanisasikan dan dibeli melalui devaluasi nilai tukar domestik (atau untuk mengganti pembayaran hutang) dengan perusahaan asing atau kerja-sama dengan alat tukar asing dari luar negeri. Akhirnya, debat privatisasi adalah suatu hal yang percuma. Tidak lebih dari debat tentang efisiensi produktif ketimbang distribusi keadilan.

\section{Apakah Kebebasan Pasar Sama dengan Kebebasan Demokratik?}

Dengan pengamatan selintas, adalah aneh memahami pasar bebas 'kapitalisme dan pemilihan politik demokrasi' sering diidentikkan, meski pun mereka tidak dapat dipisahkan atau bahkan dibedakan dengan suatu pertimbangan yang lebih jauh, model baru ini mungkin sedikit lebih menjanjikan ketimbang membela ketidaksetaraan pasar yang lebih kapitalistis atau pemerlemahan determinasi- diri (self-determination) demokrasi.
Seperti uang, demokrasi elektoral tampak sangat menggairahkan, khususnya bagi mereka yang jarang menikmatinya. Akibatnya, mudah menerima berbagai hal seperti Pemilu multipartai dan pers yang bebas dengan berbagai debat dan pilihan politik lainnya. Ini khususnya menggejala dalam kasus di bekas 'Sosialis' Timur, di mana Birokrasi Partai Komunis yang opresif dan Dominasi asing telah melumpuhkan pembangunan ekonomi dan ekspresi politik. Kembalinya pemilu demokratik juga disambut di beberapa negara di Selatan, di Amerika dan Asia Tenggara, di mana militer atau rejim-rejim otoritarian lainnya yang telah menyeret mereka ke dalam jebakan hutang. Biaya sosialnya adalah, pertama, puluhan atau ribuan pembunuhan, penculikan, penyiksaan, baru kemudian meningkatnya kelaparan, penyakit-penyakit, kematian dini dan kriminalitas.

Seluruh generasi menderita kemerosotan kesempatan hidup secara tragis. Itu seharusnya tidak perlu terjadi jika dicatat bahwa seluruh hal ini secara kuantitatif dan kualitatif lebih memburuk di (kapitalis) Selatan ketimbang dalam Sosialis timur. Betapapun, demokrasi-demokrasi baru menawarkan sedikit harapan untuk membalik tragedi kemanusiaan.

Di hadapan sejarah dunia material ini, sebagian orang kini mungkin berharap untuk menggabungkan demokrasi dengan pasar bebas dan/atau kapitalisme. Di timur, kebanyakan orang mengasosiasikan dengan janji-janji masa depan yang cemerlang. Di selatan, betapapun, kapitalisme digabungkan dengan pengalaman pahit di masa silam dan masa kini. Di beberapa negeri, suramnya ekonomi negara juga menantang negara demokratik. Yang tidak menguntungkan, di ujung-ujungnya, sebagai misal, tengah sibuk merasakan kepahitan yang sama dari demokrasi pasar (jumlah hutang) seperti Argentina, Brazilia dan Filipina di ta- 
hun-tahun belakkangan.

Di sisi lain, sukses-sukses NIB Asia Timur dan Jepang jarang dikaitkan dengan demokrasi elektoral. Jepang menyelenggarakan pemilu, tapi Partai Demokratik Liberal (LDP) telah menjadi dominan hampir sama lamanya dengan Partai revolusioner Institusional (PRI) di Mexico. Bahkan, LDP dan fraksi PRI tidak mencerminkan alternatif pilihan politik seperti kepemimpinan personal. Korea selatan, Taiwan, dan Singapura memiliki kemakmuran di bawah rejim otoritarian yang sempurna, dan kini baru permulaan hasil dalam respon sukses ekonomi. Di Hongkong, tentu saja, masih terdapat gugatan terhadap berbagai demokrasi politik yang tengah dihibahkan Cina daratan. Cina Hongkong, sebaliknya, menghendaki penentuan nasib sendiri secara demokratik.

Tentu saja kontroversial untuk merekam hal itu tanpa suatu rejim Barat atau Selatan yang berhubungan dengan 'imperialisme' dan 'Kolonialisme' di masa silam dan 'Pertukaran Tak seimbang' saat ini, Barat tidak akan dapat mempertahankan kepentingan dan kebutuhan pokok ekonomi, pendapatan, sosial-demokrasi, juga demokrasi politik mereka. Di sayangkan untuk itu semua, negeri-negeri Sosialis di Timur hanya sedang-sedang saja menarik keuntungan aliran pendapatan dari Selatan.

Alasan-alasan kegagalan ini setidaknya terjadi tidak memadainya perencanaan sosialis di negerinya sendiri ketimbang kegagalannya di pasar dunia luar. Posisisi ketergantungan Selatan membuatnya mengalami penderitaan panjang baik secara ekonomi, sosial dan politik dari dukungan bahwa pembangunan ekonomi dan demokrasi politik di Barat.

Dunia ketiga merupakan kasus yang paling jelas bagi jatuhnya pemilu demokratis untuk membangun dunia material atau mengimplementasikan kebijakan ekonomi- nya. Di mana pemerintahan demokratik melampaui dunia material atau bahkan kebijakan ekonomi jenderal-jenderal Junta dari Videla Ke Galtieri, dan presiden-presiden terpilih seperti Alfonsin dan juga Menem? Semuanya melaksanakan suatu kebijakan perampingan yang tidak populer dan seluruhnya gagal untuk memuaskan baik hasrat konsumen rakyat dan produsen pembangunan bangsa/negeri/negara. Sesudah krisis mencapai satu setengah dekade, pada 1989 pendapatan nasional menurun hingga 10 persen dari pendapatan rakyat merosot hingga 50 persen. Pada 1980, pembagian upah dan gaji menurun hingga 50 persen menjadi 20 persen pendapatan nasional. Kini Presiden Perancis yang populer, Presiden Menem, mendesakkan kebijakan perampingan ekonomi seperti pernah dilakukan Alfonsin pendahulunya.

Di Peru di bawah pemilihan secara demokratis Presiden Alan Garcia pendapatan nasional jatuh 20 persen di 1989 dan rakyat Sosialișme Demiokrasi Afrika mungkin lebih daripada 50 persen. Pertanyaanya apakah pemerintahan demokratik melampaui dunia material dengan, oleh, dan untuk rakyat?

Seperti di rekam di atas, suara rakyat Peru menentang kebijakan stabilisasi IMF yang menawarkan kandidat Vargas Llosa dan kemudian memilih 'kuda hitam' Alberto Fujimori. Namun Presiden baru ternyata jugämelaksanakan kebijakan ekonomi yang serupa dengan rivalnya yang ia tantang dan ditolak dalam pemilu.

Di Amerika tengah, krisis ekonomi merusak ekonomi di seluruh negeri dengan merata, merontokkan demokrasi di Costa Rica, kurang-lebihnya penunggangan kekuatan militer dibelakang presiden terpilih di el Salvador dan Guatemala, atau bekas Sosialisme Marxis di Sandinista yang diperintah Nicaragua, yang diimplementasikan condicionalidad sin fondo kesepakatan- 
nya sendiri, sepert diobservasi di atas. Tentunya, perang Contra dukungan AS membantu menggejalanya tingkat inflasi melampaui 30,000 per sen selama setahun.

Nicaràgua hadir dengan suatú pilihan antara kesinambungan konskripsi dan perang (diajukan Bush menentang, Sandinista) dan uang (ditawarkan Bush pada Chamoro). Rakyat Nicaragua memilih uang dan perdamaian. Tapi, pihak yang menang hanya mampu menciptakan situasi damai tanpa sedikit pun uang yang dijanjikan. $\mathrm{Pe}-$ milu Panama dan Presiden Endara sampai mogok makar dalam usahanya mendapatkan uang yang ia janjikan untuk rakyatnya. Namun akibat embargo dan kemudian invasi, rakyat Panama kini sekitar 50 persen pengangguran.

Bahwa jerman Timur seperti Nicaragua dan berbagai pemilihan normàl, juga disuarakan dengan buku panduan mereka. Tapi berapa jauh fungsinya? mereka menjadi koloni ekonomi yang tergantung barat dan mendapatkan 2 juta, bahkan menjadi 3 juta pengangguran yang tidak ia tawärkan.

Mengapa seluruh suara pemilu dilakukan dengan panduan mereka?, jawabnya adalah karena mereka tidak punya pilihan. Pilihan Hobson dan pemerintahan terpilih mereka telah saling mendukung menjatuhkan seluruh pemilu ini dan lainnya. Mengapa terjadi dan terus dilakukan seluruh pemerintah untuk mengikuti kebijakan ekonomi yang pada intinya sama menghadapi lingkungan ekonomi material yang sama. Mereka semua melakukannya karena harus melakukannya dengan kemungkinan pengecualian. rejim Kohl di Jerman (Barat), yang mungkin masih punya sedikit pilihan penting tapi kian merosot peranannya. Pemerintahan Kohl memilih mengabaikan kehendak 'rakyat', dan memenuhi tuntutan struktural.

Hal itu telah, dan kini seringkali pada, ekonomi dunia yang menyusun margin de- kat pilihan dan kebijakan demokrasi. Apakah pemilu hanya memilih pemimpin politik di setiap kedaulatan nasional, rumah perahu di tengah gelombang arus perubahan ekonomi dan serbuan badai krisis, melampaui pemerintah yang tidak mengontrol apa pun?

Andaikata pará pelayan dan atau penumpang dapat di atur kembali di dek kursi Titanic, menjadi struktur yang memiliki kekuatan lebih demokratik yang ditentukan dengan, oleh, dan untuk rakyat, hal yang terjadi tetap sama. Pada.Titanic 80 persen penumpang kelas empat tewas, 60 persen kelas tiga, 40 persen kelas kedua dan 20 persen . kelas pertama. Orang Kaya dan sangat Kuat setidaknya memiliki pilihan demokratis pertama, baik .pada Titanic maupun di mana saja, Uang berbicara lebih keras ketimbang gagasan-gagasan (idealideal).

Jadi ketika Fùkuyama mengatakan 'kita telah menjeláskan bahwa suatu revolusi penting sedang berlangsung di dunia, dan dalam revolusi itu, ide-ide menjadi penting (Fukuyama, 1989), kita seharusnya menguji suatu kasus yang lebih mengkhawatirkan dâripada pernyataannya mengenai ide-ide yang mungkin menjelma dan mengapa semua itu begitu penting. Adalah klaim-klaim ideologis yang mengatakan bahwa yang terjadi di Jerman atau di mana saja karena demokrasi atau nasionalisme. Keduanya hanyalah menutupi desakan material.

Di sana terdapat sedikit basis material, untuk mengharapkan peningkatan yang menentukan dalam hubungan ekonomi-politik dalam ekonomi dunia di masa depan. Sebaliknya, pembangunan material dalam ekonomi dunia mungkin membuat hal-hal buruk dalam jangka pendek dan menengah/ panjang. Sepanjang beban hutang tetap ada dan bahkan meningkat di masa depan, ekonomi yang di selatan akan terus menderita 
Topik: Memasarkan Demokrasi di Tengah Pasar yang Tidak Demokratik, Andre Gunder Frank

dan hutang akan bertambah menantang demokrasi mereka. Hal itu masih sesuatu yang teriampau muluk jika tetap ditunggangi hutang, baik demokrasi-demokrasi di Polandia, Hungaria atau pun di mana saja di Eropa Timur.

Berbagai pengaturan finansial IMF atau term-term komersial Bank Eropa untuk rekonstruksi dan Pembangunan, sukar dihindari hanya melanggengkan dan memperberat beban dan bahaya ini. Kebijakan yang sama juga akan melanggengkan hal yang sama di bagian lain eropa timur dan tengah, tetapi mungkin juga Republik Baltik.

Pembangunan jangka panjang material ekonomi dunia dan pemecatan buruh semakin meminggirkan berbagai bagian dunia ketiga di sepanjang pantai Afrika. Bahkan, kemajuan industri dan budidaya-pertanian dan penurunan di barat juga memarginalisasikan pertumbuhan populasinya pada masalah rasial, etnik dan obat-keras dan perkampungan kriminal.

Saat ini, pengangguran massif, peningkatan diferensiasi regional dan polarisasi sosial juga bergulir di Timur, juga mendorong marginalisasi ekonomi, sosial dan politik serupa. Bahkan, di bagian selatan Balkan dan mantan Uni Soviet, juga dapat dimasukkan bagian barat dan daerah Cina lainnya, marginalisasi ini masih menunjukkan bekas-bekasnya

Merupakan fenomena yang sulit dijumpai, Pasar dan Demokrasi, atau Kebebasan ekonomi dan politik, berjalan seiring. Kenyataannya, Dalam demokrasi pemilihan, satu orang satu suara. Di Pasar, Satu Dollar satu suara. Karena itu, kaya dollar, kaya suara; tak punya dollar, tak punya suara. Tapi cenderung untuk menjadi terpinggirkan tidak hanya dari voting ekonomi, tapi juga cenderung disingkirkan dari voting politik. Adalah bukan kebetulan bahwa banyak orang miskin suaranya terpinggirkan setidaknya dalam pemilu. Di AS, 50 persen suara orang miskin, yang menggelandang dan tak punya alamat tidak punya hak suara.

Serupa dengan itu, mereka yang tidak punya atau mencari beberapa atau sedikit dollar di luar tapi hanya pesos atau zlotys di dalam juga terpinggirkan baik secara ekonomi maupun politik, dalam sistem dunia, kecuali mereka kini punya marks atau yen. Pertemuan Ekonomi tahunan (sesungguhnya politik) (G-7) menawarkan illustrasi nyata prinsip ini, memaparkan hanya Kanada dan Italia pada lingkaran mereka yang memiliki noblesse obliged tradisional. Pengambilan keputusan yang nyata hanya terbatas pada G-3 Yakni Bank Sentral AS, Jerman dan Jepang, dengan Inggris dan Prancis di luarnya. Demikian pula dalam forum 24 OECD atau Dewan pertemuan Majelis Umum PBB, yang hidup di dunia kedua dan ketiga di Selatan dan Timur, tidak punya hak bicara dan Suara yang nyata.

Yang paling mengerikan, pasar tidak hanya mengeluarkan mereka yang tanpa dollar dari pengaruh politik di dalam atau di luar. Tapi bekerjanya pasar di sektor domestik maupun internasional juga hanya memperkaya yang sudah kaya dan mempermiskin yang sudah miskin dan bahkan lebih menyingkirkannya. Bibel menunjukkan pada kita bahwa hal ini bukan sesuatu yang baru dalam kenyataan hidup bahwa "dari mereka yang memiliki akan diberikan; dan dari mereka yang tidak memiliki, akan diambir' .

Tentu saja, Pasar seperti suatu lottere, menawarkan kesempatan yang sama, dan ilusi untuk beberapa yang beruntung , untuk mendapatkan posisi yang lebih baik dari permainan itu, legal atau tidak legal, moral atau immoral. Kesempatan itu adalah apa yang membuat pasar -dan lotere-nampak demikian atraktif termasuk mereka yang menjadi pecundang. Pasar kemudian juga akan berupaya untuk memobilisasi diri 
mereka melalui gerakan sosial untuk menguji bentuk demokrasi yang lain.

\section{Kedaulatan Demokrasi dalam Suatu Ekonomi Global: Kontradiksi dalam' Termin}

Dapat dikatakan, bahwa bekerjanya ekonomi global menghalangi upaya kedaulatan nasional dan pelaksanaan keputusan demokratik sejati - yang berasal dari rakyat, untuk rakyat, dan untuk rakyät-, khususnya di negera dunia ketiga. Alasanalasan untuk ketidakmungkinan demokrasi liberal representatif ini sudah cukup jelas, dan kita di sini hanya menyebut beberapa yang secara internal dan eksternal menjadi perhatian berbagai negeri.

Kelebihan demokrasi liberal yang menghasilkan parlemen yang baru terpilih secara demokratis, dapat dikatakan tidak lebih dari omong-kòsong selamia kekuasaannya dibatasi UU Kehakiman seperti di Chili. Jenderal Pinochet mengangkat dirinya sebagai Pimpinan Komando Angkàtan Bersenjata dan secara meluas mengumumkan bahwa tentara bebas dan tidak di kontrol secara demokratis oleh presiden terpilih, juga . tidak bertanggung jawab kepada parlemen. Bahkan sebelum meninggalkan kantor kepresidenan Jenderal Pinochet memperkenalkan perubahan administrasi ekonomi secara umum, dan Bank Sentral pada khususnya, yang secara mendalam dan efektif mempengaruhi parlemen atau presiden mengatasi seluruh serial keputușan ekonomi yang vital.

Ini baru lapis permukaan; bagi pemerintahan demokratis baru di Chili, juga di mana saja, ini merupakan kasus yang mengharuskan pengejaran kebijakan-kebijakan ekonomi yang sama yang didorong penguasa militer yang tidak demokratik.

Bahkan, pengaturan Chili pada khususnya hanya sebagian contoh pembatasan umum yang tersebar-luas untuk melatih demokrasi dengan- bersama-dan- untuk- rakyat. Kendala struktural yang sangat jelas itu adalah bahwa. di seluruh dunia ketiga dari Filipina hingga Asia Selatan dan. Barat; Afrika dan dalam Amerika Latin, kekuatan Angkatan bersenjata tetap berdiri di belakang rejim demokratik.yang baru berdiri. Pemerintahan yang terpilih secara demokratis di Pakistan, Thailand, Haiti, dan Peru akhirnya ditaklukkan tentara mereka, demikian pula Aquino di Filipina atau Presiden Alfonsin dan Menem di Argentina, dikepung berbagai usaha kup militer yang beragam.

Presiden sipil, juga parlemen, di ElSalvador dan Guatemala tidak berdaya menghadapi kekuatan efektif militer mereka. Di Brazil dan di mana saja di Amerika Latin, senasib dengan Afrika, pilihan-pilihan mereka ditentukan dan di batasi ancaman pedang Democles militer. Pedang tersebut mungkin melayang kembali di mana saja, seperti di Thailand, Pakistan, Haiti dan Peru.

Kekuatan-kekuatan militer ini dan perwira-perwira yang memimpin mereka sering dilatih dengan, dan tetap di bawah pengaruh dari, kekuatan barat. Bahkan, jika tidak berkuasa, mereka masih memiliki tangan atas banyak hal melalui elite ekonomi demokratik negeri mereka masing-masing. Mereka tetap mengupayakan dan melanjutkan mengejar kebijakan ekonomi yang menguntungkan mereka dan konco-konco luar negerinya. Kebijakan-kebijakan itu pasti tidak didesain atau diimplementasikan dalam kepentingan mayoritas rakyat atau dalam kesepakatan dengan gairah yang mereka ekspresikan melalui suara demokrasi. Parlemen dan sebagian besar presiden yang terpilih secara demokratis berikut menteri-menteri mereka tidak dalam posisi yang dimaksudkan untuk mengejar berbagai kebijakan ekonomi alternatif.

Namun kendala struktural yang terbesar untuk membina kebijakan demokrasi 
dengan, oleh dan untuk rakyat justru pada partisipasi dan posisi mereka dalam ekonomi dunia, yang tidak dapat mereka kontrol. Untuk mengatakannya dengan jalan memutar, efektifitas demokrasi untuk membatasi diri dari rumusan dan implementasi kebijakan politik domestik yang relatif tidak penting dibendung intervensi efektif oleh keputusan kebijakan ekonomi yang dibuat di luar rangka demokrasi dengan, oleh, dan untuk rakyat. Karena yang terburuk bagi kebijakan ekonomi di mana saja justru bukan terletak pada kondisi-kondisi kebijakan ekonomi domestik, tapi kebijakan ekonomi asing yang mungkin mengintervensi proses-proses politik dan pemerintahan di dalam berbagai negeri.

Kita mungkin dengan ringkas hanya menghubungkan dua contoh kaitan keputusan kebijakan ekonomi Amerika, yang memiliki konsekuensi ekonomi dan politik di seluruh dunia. Pada Oktober 1974 diputuskan Pimpinan Federal Reserve AS, Paul Vocker, untuk meningkatkan suku bunga dan nilai dollar, sehingga menjadi faktor terpenting satu-satunya dari krisis hutang, depresi serta 'lenyapnya dekade' 1980 'di banyak dunia ketiga.

Keputusan yang sama juga di dorong resesi, yang dimulai pada 1979 dan ditopang oleh terpilihnya Ronald Reagan di kursi kepresidenan. Secara hukum, pemilihan dan Kongres Amerika dan bahkan presiden Amerika, tidak punya hak untuk mencampuri keputusan Federal Reserve. Kedaulatan Hukum dan politik; seperti seluruh' realita ekonomi, mencegah berbagai demokrasi atau pengaruh lain dengan, oleh dan untuk rakyat di berbagai bagian dunia ketiga melalui keputusan yang secara vital menentukan kesejahteraan ekonomi dan̂ pilihan politik untuk rakyatnya.

Tanggapan Reaganomik terhadap Resesi 1979-82 pada kepresidenan Amerika dan Kongres kemudian mempaket tahap untuk peristiwa besar di dunia 1980 dan 1990. Bertentangan dengan ideologi untuk 'menempatkan pemerintah di belakang punggung kita' dan menghapus defisit dan hutang AS. Keynesianisme Militer Reaganomik meningkatkan defisit belanja, mempromosikan defisit perdagangan, melipattigakan hutang luar negeri AS menjadi 3 trilyun dollar, dan akhirnya pada tahun 1986 telah mengubah AS sebagai negara dengan hutang terbesar di dunia. Namun, permintáan dana kegiatan yang terjadi akibat ditingkatkannya pengeluaran militer dan pinjaman domestik dan luar negeri pada saat yang sama oleh AS telah mempertahankan ketidakjelasan tidak hanya ekonominya sendiri pada 1980, tapi juga seluruh negeri barat dan Asia Timur.

Harga-harga yang lahir tanpa diketahui dan disadari di Uni Soviet, Eropa Timur, Asia Tengah, Afrika dan Amerika latin, juga lainnya. Resesi dunia sejak 1979, bersama dengan kebijakan ekonomi Amerika, telah mengakibatkan menurunnyá sumber pertukaran asing Uni Soviet melalui ekspor minyak dan emas.

Hal itu disusul pengeluaran militer Presiden Reagan untuk Perang-Bintang dan mendukung pemberontakan bersenjata regional menentang pemerintahan Afganistan, Ethiopia, Mozambik, Angola, Nicaragua dan negara pecahan Uni Soviet lainnya menuju' kebangkrutan dan inflasi mata uang. Perestroika dan kegagalannya, merupakan akhir perang dingin dan sekaligus Uni Soviet sendiri, baik secara ekonomi maupun politik.

Jadi akibát Reviolusi 1989 di Eropa Timur. Ekonomi Sosialis terperangkap krisis hutang yang sama seperti Amerika Latin dan Afrika, seperti kita amati di atas.'Eropa Timur dikelilingi resesi berat, dan baik Afrika dan Amerika Latin mengalami depresi berat di tahun 1980 dan kemerosotan tajam dalam kemampuan mereka untuk bertarung 
Topik: Memasarkan Demokrasi di Tengah Pasar yang Tidak Demokratik, Andre Gunder Frank

dalam ekonomi dunia, jika hanya investasi teknologi baru dan modal sumber daya seperti jasa-jasa sosial yang dikorbankan untuk melayani peningkatan hutang luar negeri.

Di tiga wilayah itu, pemerintahan dan rejim-rejim otoritarian yang gagal mengelola ekonomi dan kemudian juga krisis politik sangat didiskreditkan. Mereka kemudian, atau kini menjadi, ditempatkan dengan 'demokratis' -yang memiliki kesinambungan untuk mengelola krisis ekonomi yang sama. Pada tahun 1990-an, depresi berat ekonomi telah mengambrukkan Republik bekas Uni Soviet dan: Eropa Timur, yang melebar ke Afrika dan Amerika Latin. Cina dan India mencoba bertahan menerima berbagai konsekuensi-konsekuensi krisis di tahun 1980, tapi, ekonomi keduanya tidak semenderita seperti ketika membuka diri pada ekonomi dunia. Karenanya, Cina dan India kini dalam posisi yang lebih kritis dan mungkin masih tetap mengalami resesi dan depresi serius di tahun 1990-an. Bahkan, kelangsungan resesi dunia yang diperbaharui sejak awal 1990 dapat berbalik menjadi depresi yang sama di Barat.

Jadi, Reaganomics dan Thatcherisme tidak hanya diandaikan akan, tetapi juga telah, memukul kaum miskin dengan keras, seperti bänyak kelas menengah telah sering melakukannya. Bahkan polarisasi akibat Reaganomik, Thatcherisme dan kopikarbon mereka di mana pun yang membuat orang kaya semakin kaya.dan kaum miskin lebih miskin tidak dibatasi aneka ekonomi domestik atau nasional. Konsekuensinya adalah sangat meluas. Dalam ekonomi tunggal dunia ada beaya yang dilahirkan pihak yang terlemah untuk mendukung keuntungan dan kebijakan mereka yang terkuat.

Jadi bukan saja nasional, bahkan dunia, pemilu atau pemilihan demokratis nasional atau parlemen dunia yang terpilih secara demokratis pernah mendapatkan suatu kesempatan, untuk memilih di antara polarisasi ekonomi dan kebijakan dunia atau alternatif lain yang mungkin.

Demokrasi liberal parlementer dengan pemilu atau secara demokratis menerima kesempatan untuk memilih di antara polarisasi ekonomi dan politik dunia atau berbagai keputusan yang mungkin lainnya. Demokrasi Parlementer liberal di sejumlah, negara dan demokrasi di 100 negeri bahkan hanya mampu sedikit!

Untuk melatih pemerintahan demokratis sejati dengan, oleh dan untuk rakyat di berbagai tempat di dunia, mereka minimum memiliki suara untuk Kongres dan Presiden Amerika, yang menentukan keputusan-keputusan ekonomi dan politik dengan pengaruh vital bagi kepentingan, rakyat di dunia. Bahkan, hak suara asing dalam pemilu Amerika akan mencukupi untuk turut membantu kontrol demokrasi. Dan tidak. setiap pemilik. suara di Amerika mampu mengkontrol kebijakan ekonomi Federal Reserve; yang kini juga dipengaruhi persyaratan-persyaratan yang dipaket Bank of Japan dan Bundesbank Jerman yang juga tidak bisa dipengaruhi bahkan oleh pemilihnya sendiri.

Betapa pun, bahkan kebijakan ekonomi G-7, G-3, atau G-1 tidak otonom, apalagi secara demokrätik terkontrol. Jika mereka otonom atau mampu menjadi seperti itu, kebijakan-kebijakan mereka akan mampu mencegah kembalinya resesi dan inflasiinflasi yang mereka 'andaikan' dapat dicegah setidaknya secara bertahap. Dalam kenyataannya, ekonomi dunia menembus kontrol seluruh pembuat kebijakan, yang sebagian besar menganggapi terlalu sedikit dan terlalu lambat kalau bukan justru hanya membuat segalanya semakin buruk (Mantan Koresponden finansial Washington Post Bernard Nossiter menunjukkan ini dalam Fat Years and Lean: The American Economy Since Roosevelt, direviu Frank 1992a). 
Jika catatan suram melanda pembuat keputusan ekonomi di pusat ekonomi dunia, kebijakan ekonomi di periferi dunia ketiga -termasuk bekas negeri-negeri Sosialis Dunia Kedua -a fortiori juga tersingkir jika keputusan itu melanda pembuatan dan pelaksanaan kebijakan ekonomi.

Jadi, rakyat atau juga pemerintahan demokratik mereka di berbagai negeri dunia ketiga (dan bekas dunia kedua, kini sedang menjelma menjadi dunia ketiga) kekurangan pengaruh mengatasi ekonomi atau kebijakan dalam negeri, apalagi luar negeri, atau ekonomi dunia secara keseluruhan. Jadi, apa jenis demokrasi itu jika, tidak membantu kontrol rakyat atau berdampak untuk mengatasi berbagai peristiwa dan keputusan yang sangat penting mempengaruhi kehidupan mereka? Demokrasi pemilihan liberal ini dalam berbagai negeri yang 'berdaulat' masih lebih baik ketimbang yang lain, tapi itu bukan demokrasi sejati seperti dalam cita rasa Lincoln yakni Dari, Oleh, dan Untuk Rakyat. Tak satu pun yang mampu menjadi seperti itu. Demokrasi jenis ini menarik ketika baru diperkenalkan terutama paska masa-masa diktator yang panjang, menyajikan ilusi pada rakyat tentang kekuatan dan determinasi diri, hingga realitas membuka mata mereka seperti terjadi di Argentina, Polandia, dan di mana saja.

\section{Demokrasi - Sipil Partisipatoris .}

Jadi, demokrasi pemilihan liberal bukan demokrasi semua untuk semua - bahkan bukan demokrasi, apalagi sejarah atau ideidenya. Peningkatan lain bagian penting demokrasi adalah gerakan sosial non-partai, khususnya dalam masyarakat sipil, atau yang lazim disebut Demokrasi sipil partisipatori (Fuentes dan Frank1989; Frank dan Fuentes, 1990) .

Absennya demokrasi politik di Timur dan juga kurang suksesnya di Selatan, telah mendorong rakyat untuk mengkaji ulang gerakan sosial demokrasi sipil untuk meletakkan dasar bagi partai demokrasi terpilih di tempat tertinggi. Segala yang baru, gerakan rakyat dan Forum lainnya di bekas Jerman timur, Cekoslowakia dan Hungaria untuk mempertahankan identitas dan kebebasan mereka dari partai-partai politik baru. Tapi seluruh gerakan ini segera diliputi proses-proses pemilihan dan tekanan-tekanan negara.

Mungkin perlindungan berbagai partaipartai politik (Hungaria dengan cepat memiliki 50 buah partai), pemilu-pemilu dan parlemen-parlemen tampak demikian penting sesudah beberapa tahun tanpa mereka, dan masyarakat cenderung mengabaikan proses-proses yang sama penting dan institusi-institusi demokrasi sipil lainnya. Di Amerika Latin, gerakan sosial setidaknya punya daya-dorong untuk menampilkan kembali demokrasi pemilihan. Mereka juga lebih bertahan dan lebih baik ketika bermunculan pemerintahan demokratik, sejak mereka lebih perhatian dengan survival ekonomik rakyat, tantangan yang tetap hadir dan makin menguat.

Hal itu tetap menggejala, betapa pun, meski pemilu dan demokrasi parlementer kini digembar-gemborkan Fukuyama (Fukuyama 1992), dan lainnya menawarkan kesempatan untuk penentuan nasib rakyat sendiri dari pada demokrasi sipil partisipatori ini. Hal Itu tampaknya, secara de jure, merupakan pemilihan dan institusi-institusi negara parlementer yang baru, namun in fact seringkali justru mencabut hak pilih rakyat di Eropa timur dan bagian dunia ketiga seperti Filipina dan Korea Selatan, juga sesudah percobaan mendalam mereka dengan demokrasi partisipatori. Berapa jauh hak demokratis untuk menentukan nasib sendiri, berbeda dengan Fukuyama, mampu menjamin institusi-institusi ini dan berguna bagi rakyat, khususnya jika 
ekonomi mereka terbelakang (diduniaketigakan)?

Adalah tragis jika saat ini pemberangusan demokrasi sipil dilakukan dengan menerapkan demokrasi politik melalui partaipartai politik, yang konteks pemilihan untuk pemerintahan adalah untuk menguasai negara (yang terbaik dapat di bawah tegangan ekonomi eksternal dan domestik). Bagi Barat dan Selatan, itu semakin melengkapi demokrasi politik di mana saja, tepatnya karena pembatasan proses-proses pemilu diorganisasi melalui partai-partai politik. Namun gerakan-gerakan sosial dapat membantu memobilisasi rakyat untuk berbagai tujuan ekonomi, sosial, kultural, dan politik dan permintaan penduduk, yang pemilu dan pemerintah tidak dapat mengkondisikannya tanpa tekanan rakyat yang dilatih melalui demokrasi sipil ini. Krisis ekonomi yang sama di Selatan juga mendorong orang untuk mengorganisasikan dan memobilisir diri mereka dalam gerakan sosial akar rumput.

Gerakan-gerakan ini memajukan demokrasi partisipan dan produksi serta distribusi alternatif untuk mempertahankan mata pencaharian dan identitas menentang pengrusakan ekonomi, serta menolak didominasi oleh negara. Tentunya, seperti diamati di atas, krisis ekonomi di Eropa Timur dan bekas Uni Soviet lama dipenuhi gerakan sosial untuk meminta dan memajukan perestroika ekonomi yang sama dan glasnost politik di sana. Kebutuhan untuk gerakan sosial yang sama dan berbeda dalam dan melalui masyarakat sipil akan tetap ada sesudah penegakan pemilihan terpilih berdasarkan partai-partai politik.

Pada saat yang sama, gerakan sosial dalam masyarakat sipil, tidak sedikit dan seringkali lebih daripada partai-partai politik dalam pemerintahan, merepresentasikan kepentingan regional dan etnik atau kepentingan dan permintaan nasionalis. Idealnya, masing-masing (pemerintah dan ornop) mengakui kesamaan hak keberadaan institusi-institusi politik negara, juga komunitas masyarakat internasional. Kekhawatiran yang terburuk dapat diamati di bekas negara Yugoslavia dan Uni Soviet, di mana etnik dan kelompok nasionalis telah dipadukan dalam pertarungan bersenjata yang diperbaharui dengan proses-proses balkanisasi yang berbeda.

Bahkan, kebangkitan nasionalis dan etnik otoritarian ini adalah hasil rongrongan krisis yang sama dalam ekonomi dunia, khususnya di daerah Selatan dan Timur, di mana privatisasi ekonomi dan demokrasi politik secara ideologis diperjualbelikan sebagai keyakinan-mantap yang final ketika realitas di luar- sana tak punya akhir sejarah.

\section{Ringkasan}

Seperti uang, demokrasi sangat menggairahkan. Khususnya bagi mereka yang jarang menikmatinya. Tapi, seperti juga uang, keputusan-keputusan yang dikendalikan 'mereka' dan bukan 'kita' mungkin digunakan sebagai instrumen-instrumen untuk opresi dan eksplotasi. Hal itu lazim terjadi ketika kontrol efektif demokrasi, seperti uang, dimonopoli segelintir orang yang ditentang mayoritas. Hal itu juga berlaku di pasar, khususnya Pasar dunia. Pasar (Dunia) mengkonsentrasikan uang dan keputusan, demokrasi atau semacamnya, di tangan orang-orang tertentu dengan mengorbankan mayoritas.

Meluasnya demokrasi politik di Selatan dan Timur, yang terjadi dengan alasan-alasan yang berbeda, bukan merupakan kekuatan yang memadai untuk menghalangi, membatalkan, menandingi apalagi melenyapkan kekuatan ekonomi yang bekerja di dunia. Kekuatan ekonomi lebih menentukan kesejahteraan banyak orang daripada 
Topik: Memasarkan Demokrasi di Tengah Pasar yang Tidak Demokratik, Andre Gunder Frank

keputusan-keputusan mereka sendiri atau pemerintah yang mereka pilih secara demokratis. Dan juga, berbagai kekuatan ekonomi dunia ini pada umumnya melampaui kendali siapa pun. Tidak jarang himbauan demokrasi politik hanya merupakan ikhtiar untuk menutupi ketidakmampuan mengelola peristiwa-peristiwa mereka, yang rakyat dalam demokrasi-demokrasi ini diekspos. Demokrasi Partisipasi sipil dalam Masyarakat Sipil merupakan jawaban Rakyat dan Media alternatif perjuangan mereka. 